\title{
The effects of diet and temperature on enzymes, hormones, and fecundity of the African Catfish Clarias gariepinus (Burchell 1822)
}

\author{
Waleed Abdul-Aziz A. Al-Deghayem, El Amin Mohamed Suliman* \\ Department of Zoology, King Saud University, Riyadh 11451, Saudi Arabia
}

\begin{tabular}{|c|c|}
\hline $\begin{array}{l}\text { Article history: } \\
\text { Received on: July } 17,2018 \\
\text { Accepted on: October } 04,2018 \\
\text { Available online: March } 15,2019\end{array}$ & $\begin{array}{l}\text { The aim of this study was to check the effect of multiple temperatures and various protein diet formulas on liver } \\
\text { enzymes, gonadotropins, and growth hormone }(\mathrm{GH}) \text { using African catfish Clarias gariepinus. } C \text {. gariepinus was } \\
\text { exposed to multiple temperatures }\left(T_{24}{ }^{\circ} \mathrm{C}, T_{28}{ }^{\circ} \mathrm{C} \text {, and } T_{32}{ }^{\circ} \mathrm{C}\right) \text { and various protein diet formulas: } D_{1} \text { (fishmeal-based } \\
\text { diet), } D_{2} \text { (soymeal-based diet), and } D_{3} \text { (pea-meal based diet). Tilapia commercial feed }\left(D_{4}\right) \text { was used as reference diet. }\end{array}$ \\
\hline $\begin{array}{l}\text { Key words: } \\
\text { Hormones, } \\
\text { Enzymes, } \\
\text { Fecundity, } \\
\text { Temperature, } \\
\text { Diet }\end{array}$ & $\begin{array}{l}\text { A total of } 720 \text { individuals with an average weight }(101-104 \mathrm{~g}) \text { were stocked at a density of } 20 \text { individual fish per tank } \\
\text { in } 12 \text { tanks of three replicates. Liver enzymes, gonadotropins, GH, and fish fecundity were measured after } 16 \text { weeks. } \\
\text { The results revealed that liver enzyme like glutamate-oxaloacetate transaminase was significantly }(P<0.05) \\
\text { lowered at } T_{28}{ }^{\circ} \mathrm{C}: D_{2} \text { diet, while glutamic pyruvic acid transaminase was lowered by } T_{28}{ }^{\circ} \mathrm{C}: D_{4} \text { diet. However, } \\
\text { no effect was observed on creatinine }(P>0.05) \text { at any experimental condition. Follicle-stimulating hormone and } \\
\text { luteinizing hormone were significantly }(P<0.05) \text { increased at } T_{28}{ }^{\circ} \mathrm{C}: D_{1} \text { diet and } T_{32}{ }^{\circ} \mathrm{C}: D_{1} \text { diet, respectively. GH was } \\
\text { significantly }(P<0.05) \text { increased by } T_{28}{ }^{\circ} \mathrm{C}: D_{1} \text {. The relative weight of the ovary of } C_{\text {. }} g a r i e p i n u s \text { was significantly }(P \\
<0.05) \text { increase at } T_{32}{ }^{\circ} \mathrm{C}: D_{1} \text {, while the testis relative weight was increased with } T_{24}{ }^{\circ} \mathrm{C}: D_{3} \text {. The result from this study } \\
\text { revealed that there is a direct relationship of temperature on fish fecundity, enzymes, and reproductive hormones } \\
\text { in } C \text {. gariepinus. The temperature of } 28^{\circ} \mathrm{C} \text { along with fishmeal or soy-meal positively improved the fecundity and } \\
\text { health of fish. }\end{array}$ \\
\hline
\end{tabular}

\section{INTRODUCTION}

Clarias gariepinus (the African catfish) is an important cultured fish in the tropical and subtropical areas [1]. C. gariepinus is a well-known fish for fast growth rate and resistance to adverse conditions such as handling, temperature fluctuation, low oxygen, deteriorated water quality, and high stocking density [2]. The aquaculture of African catfish expanded greatly in the 1970s and 1980s [3,4]. The aquaculture of $C$. gariepinus is suitable in developed and developing countries both biologically and economically [5].

Various fish diets were tested by researchers in the past to optimize the growth of fish without affecting the health of fish [6]. The fluctuation in temperature and nutrition could induce the stress which, in turn, could affect the fish in aquaculture system [7,8]. Optimum water temperature allows fish to grow faster and healthier. Water temperature and fish feeding rate are the most important factors that affect the growth of fish [9]. The fish metabolic rate is significantly affected by water temperature. The decrease in water temperature increases the activity of tissue enzyme [10,11]. Growth hormone $(\mathrm{GH})$ would also influence

*Corresponding Author:

El Amin Mohamed Suliman, Department of Zoology, King Saud University,

Box: 2455, Riyadh 11451, KSA.

E-mail:elaminsuliman@yahoo.com by changing environmental conditions [12,13], fish nutrition [14], and feed ingredients [15].

Pituitary gonadotropins, follicle-stimulating hormone (FSH), and luteinizing hormone (LH) play a central role in regulating gametogenesis and gonadal hormones production which are required for the development of sexual behavior and secondary sex characters in all vertebrates $[16,17]$. Early developmental stages of the gonads such as vitellogenesis and spermatogenesis are stimulated by FSH, while later stages such as ovulation and spermiation are stimulated by LH [18].

Fish fecundity is an important tool of fishery biology; it has a direct effect on fish stock recruitment and management as well as fish production. Fish fecundity is defined as the number of eggs just before spawning [19].

In the present study, we have investigated the response of liver enzyme, reproductive parameters, $\mathrm{GH}$, and fecundity of the fish by four different types of diets comprising of altered protein source at three different temperature conditions using African catfish C. gariepinus.

\section{MATERIALS AND METHODS}

\subsection{Experimental Fish}

African catfish C. gariepinus was obtained from the King Abdul Aziz City of Science and Technology research station. 720 fish with an 
average weight between 101 and $104 \mathrm{~g}$ were randomly selected and stocked in 12 tanks with three replicates at a density of six males and seven females per tank at Zoology Department, King Saud University, Kingdom of Saudi Arabia. 2 weeks before the start of the feeding trials, a commercial feed containing $36 \%$ crude protein was fed to fish twice a day at $2 \%$ of fish weight.

\subsection{Fish Feed Formulation}

The following feed having $36 \%$ crude protein was: Diet $1\left(D_{1}\right)$ the control was formulated of fishmeal, wheat, vitamin, and mineral premix, and fat. Fishmeal was partially replaced with soybean meal in diet $2\left(D_{2}\right)$ and Pea-meal in diet $3\left(D_{3}\right)$, while $D_{4}$ was ARASCO commercial diet ( $36 \%$ crude protein) is used as a reference. Fish were fed 3\% per body weight 3 times on a daily basis.

\subsection{Water Quality}

Water quality parameters such as temperature, $\mathrm{pH}$, dissolved oxygen, ammonia, nitrite, and nitrate were monitored weekly throughout the study. The temperature was measured using a mercury-in-glass thermometer, while the dissolved oxygen and $\mathrm{PH}$ were measured using a dissolved oxygen meter HANNA-HI9142 model and HANNAHI98107 model, respectively. Water temperature $\left(T_{2}, T_{2}\right.$, and $\left.T_{3}\right)$ was controlled by heaters at three different levels for each diet as $\left(T_{24}{ }^{\circ} \mathrm{C}\right.$, $T_{28}{ }^{\circ} \mathrm{C}$, and $T_{32}{ }^{\circ} \mathrm{C}$ ), respectively.

\subsection{Enzymes and Hormones}

Blood was drawn from arterial caudalis with heparinized syringes to measure the level of glutamic pyruvic acid transaminase (GPT), glutamic oxaloacetic acid transaminase (GOT), and creatinine following the method as described previously [20]. LH, FSH, and GH were measured using blood serum using a commercial kit of enzyme immunoassay.

\subsection{Sperm Morphometry}

The abdominal cavity of each fish from different treatments was dissected and testis were removed and prepared for scanning electron microscopy using JSM-6380 LA scanning electron microscope by following the methods as described previously [21] at an accelerating voltage of $0.3-30 \mathrm{kV}$, Appendix V. The length and width of the sperm head, mid-piece, and tail were measured and recorded [Figure 1].

\subsection{Fish and Gonadal Measurements}

The weight of each fish (C. gariepinus) was measured with a digital balance at the start and end of the experiment. The length of each fish was measured before the beginning and at the end of the experiment using a ruler. The results were recorded. The ovaries and testis were removed from all of 120 individual fish from experimental and control group, and their relative weights were recorded.

\subsection{Fecundity Determination}

Fish fecundity was quantified by taking three samples of ovaries weighing $1 \mathrm{~g}$ each from each experimental and control group. The anterior, middle, and posterior regions of both ovaries from each fish were used to collect ovaries subsamples as described [22]. The subsamples were spread evenly on a counting slide with a few drops of water, and the number of mature ova was counted, and the average number of three areas was used to determine the fecundity using following formula.
Fish fecundity $=\frac{\text { Number of ova in the subsample } \times \text { total o var y weight }}{\text { Weight of subsample }}$

Eggs within each subsample were counted for both ovaries, and the mean number of eggs was used to calculate a number of eggs per gram of fish [23]. The fecundity of C. gariepinus related to fish weight and fish length was also measured.

\subsection{Statistical Analysis}

All values were recorded as a mean \pm standard deviation and subjected to two-way analysisof variance using $95 \%$ confidence level to test for significant differencesbetween the various treatment means obtained for enzymes and hormones as described previously [24], using SPSS 10 for window software package. Regression analysis was used to measure the relationship between fecundity variables. The linear correlation coefficient $(r)$ and the coefficient of determination $\left(r^{2}\right)$ were calculated to evaluate the fit of the linear function to the imperial data. The significance of correlation coefficients for chosen relationships among the traits was subjected to the $t$-test [25].

\section{RESULTS AND DISCUSSION}

\subsection{Glutamate-oxaloacetate Transaminase, Glutamic-pyruvic Transaminase, and Creatinine}

The difference in concentration of GOT in $C$. gariepinus was statistically significant $(P<0.05)$ when the fish are exposed to various temperature levels and different diets. As shown in Table 1, the maximum concentrations of GOT were attained at $T_{32}$ and $D_{4}$, as $129.8 \mu / 1$ and lowest at $T_{28}$ and $D_{2}$ as $60.55 \mu / 1$, respectively. Similarly, the concentration of GPT in C. gariepinus males and females was significantly different $(P<0.05)$, even though exposing them to the same treatments. The highest concentration of GPT was recorded as $64.5 \mu / 1$ at $T_{28}$ and $D_{4}$ and the lowest was $36.95 \mu / 1$ which was recorded at $\mathrm{T}_{24}$ and $D_{4}$ [Table 2]. Surprisingly, the temperature or the diet alone has not affected the blood creatinine level significantly between control and treated fish; however, a significant difference $(P<0.05)$ was noted in blood creatinine level as a combined effect of temperature and diet. The maximum blood creatinine was recorded as $0.45 \pm 0.05 \mathrm{mg}$ at two experimental conditions (i) at $T_{32}$ and $D_{3}$ and (ii) at $T_{24}$ and $D_{4}$; on the other side, the lowest value of blood creatinine was $0.317 \pm 0.04 \mathrm{mg}$, which was observed at $T_{32}$ and $D_{1}$ and $T_{28}$ and $D_{2}$, respectively, experimental conditions as shown in Table 3.

Quantification of various enzymes in an animal system is essential to gauge any change in the metabolic functions or predicting any pathological changes in tissues or organs [26]. Water temperature has a considerable effect on fish metabolism. The fluctuation of temperature from the optimum level changes the concentration of GOT and GPT which has induced a negative impact on the metabolic functions of $C$. gariepinus. The GOT and GPT enzymes are also biological markers to indicate pollutant toxicity [27]. Unfavorable and stressful environmental conditions increase GOT and GPT levels in the fish blood. It has been previously shown that the concentration of GOT and GPT increases in response to damages at the cellular level [28]. The water temperature which is lower than the optimal level could enhance the activity of tissue enzymes [10]. The fluctuation in water temperature from $27^{\circ} \mathrm{C}$ to $35^{\circ} \mathrm{C}$ promoted the change in tissue enzymes in C. gariepinus [11].

The optimal concentrations of GOT and GPT were observed at $28^{\circ} \mathrm{C}$, while higher concentrations were recorded at $24^{\circ} \mathrm{C}$ and $32^{\circ} \mathrm{C}$ in this 
study. The optimal production of these enzymes at $28^{\circ} \mathrm{C}$ indicates that the physiological status of C. gariepinus was at best at $28^{\circ} \mathrm{C}$, while other temperatures induced a negative effect on the growth.

\subsection{Sex and GH}

The concentrations of LH in C. gariepinus were significantly different $(P<0.05)$ at different temperatures, diets, and their combinations. The highest concentration of LH was $0.854 \pm 0.03 \mu / 1$ which was recorded at experimental conditions of $T_{32}$ and $D_{1}$ and the concentration was lowest at the experimental condition of $T_{24}$ and $D_{2}$ which was $0.431 \pm 0.03 \mu / 1$ [Table 4]. The variability in temperature and diet also induced a significant difference in FSH concentration in $C$. gariepins. As shown in Table 5, the highest value of FSH was $0.789 \pm 0.01 \mu / 1$ at the experimental condition of $T_{2}$ and $D_{1}$ and the lowest was 0.566 $\pm 0.02 \mu / 1$ at $T_{32}$ and $D_{3}$. Similarly, the $\mathrm{GH}$ in $C$. gariepinus males and females also showed a significant difference $(P<0.05)$ at various temperatures, diets, and the combination of diets and temperature. The highest concentration was found to be $0.905 \mathrm{ng} / \mathrm{ml}$ at $T_{28}$ and $D_{1}$, and the lowest value was $0.744 \mathrm{ng} / \mathrm{ml}$ at $T_{32}$ and $D_{3}$ [Table 6].

Measurements of FSH and LH in C. gariepinus are reported to show some disruption in their activity when exerted to a sublethal concentration of 4-nonylphenol [29]. The reproductive activity of fish is regulated by the brain-pituitary-gonad axis. The vitellogenesis in female fish is regulated by FSH while; oocyte maturation is accomplished by LH [17]. In the present study, sex hormones were negatively affected

Table 1: Concentration of GOT $\mu / 1$ in C. gariepinus males and females treated with different diets and temperatures at the end of the experiment

\begin{tabular}{lccccc} 
Parameter & \multicolumn{3}{c}{ Diet } & Overall mean \\
\cline { 2 - 5 } & \multicolumn{1}{c}{$\boldsymbol{D}_{\mathbf{1}}$} & $\boldsymbol{D}_{2}$ & $\boldsymbol{D}_{3}$ & $\boldsymbol{D}_{4}$ \\
Temperature & & & & $62.26 \pm 1.48$ \\
$T_{1}$ & $62.72 \pm 3.03$ & $93.23 \pm 1.82$ & $109 \pm 1.81$ & $77.67 \pm 2.08$ & $81.97 \pm 20.0$ \\
$T_{2}$ & $82.82 \pm 1.6$ & $60.55 \pm 1.28$ & $87.47 \pm 2.76$ & $129.8 \pm 1.71$ & $77.13 \pm 10.6$ \\
$T_{3}$ & $110.5 \pm 2.15$ & $112.4 \pm 2.15$ & $128.1 \pm 17$ & $89.9 \pm 29.9$ & $120.2 \pm 12.1$ \\
Overall mean & $83.33 \pm 20.3$ & $88.73 \pm 22.1$ & $108.4 \pm 19.5$ & $93.09 \pm 24.5$ \\
\hline
\end{tabular}

$D_{1}, D_{2}, D_{3}$, and $D_{4}$ referred to different diets, and $T_{1}, T_{2}$, and $T_{3}$ referred to temperatures $T_{24}{ }^{\circ} \mathrm{C}, T_{28}{ }^{\circ} \mathrm{C}$, and $T_{32}{ }^{\circ} \mathrm{C}$ that used for the experiment, respectively

Table 2: Concentration of GPT $\mu / 1$ in C. gariepinus males and females treated with different diets and temperatures at the end of the experiment

\begin{tabular}{|c|c|c|c|c|c|}
\hline \multirow[t]{2}{*}{ Parameter } & \multicolumn{4}{|c|}{ Diet } & \multirow[t]{2}{*}{ Overall mean } \\
\hline & $D_{1}$ & $\mathrm{D}_{2}$ & $D_{3}$ & $\mathrm{D}_{4}$ & \\
\hline \multicolumn{6}{|l|}{ Temperature } \\
\hline$T_{1}$ & $51.78 \pm 1.62$ & $55.2 \pm 1.39$ & $50.35 \pm 1.34$ & $64.5 \pm 1.28$ & $55.46 \pm 5.78$ \\
\hline$T_{2}$ & $42.3 \pm 2.16$ & $52.03 \pm 4.49$ & $53.93 \pm 1.16$ & $36.95 \pm 1.72$ & $46.3 \pm 7.55$ \\
\hline$T_{3}$ & $47.9 \pm 1.24$ & $42.2 \pm 1.54$ & $37.98 \pm 1.72$ & $42.33 \pm 1.1$ & $42.6 \pm 3.83$ \\
\hline Overall mean & $47.33 \pm 4.32$ & $49.81 \pm 6.29$ & $47.42 \pm 7.16$ & $47.93 \pm 12.3$ & $48.12 \pm 7.98$ \\
\hline
\end{tabular}

$D_{1}, D_{2}, D_{3}$, and $D_{4}$ referred to different diets, and $T_{1}, T_{2}$, and $T_{3}$ referred to temperatures $T_{24}{ }^{\circ} \mathrm{C}, T_{28}{ }^{\circ} \mathrm{C}$, and $T_{32}{ }^{\circ} \mathrm{C}$ that used for the experiment, respectively

Table 3: Concentration of Creatinine $\mathrm{mg} / \mathrm{dl}$ in C. gariepinus males and females treated with different diets and temperatures at the end of the experiment

\begin{tabular}{lccccc} 
Parameter & \multicolumn{3}{c}{ Diet } & Overall mean \\
\cline { 2 - 5 } & \multicolumn{1}{c}{$\boldsymbol{D}_{\mathbf{1}}$} & $\boldsymbol{D}_{2}$ & $\boldsymbol{D}_{3}$ & $\boldsymbol{D}_{4}$ \\
Temperature & & & $0.35 \pm 0.05$ & $0.413 \pm 0.06$ \\
$T_{1}$ & $0.41 \pm 0.04$ & $0.433 \pm 0.05$ & 0.05 & $0.396 \pm 0.06$ \\
$T_{2}$ & $0.433 \pm 0.05$ & $0.317 \pm 0.04$ & $0.417 \pm 0.04$ & $0.4 \pm 0.06$ \\
$T_{3}$ & $0.317 \pm 0.04$ & $0.433 \pm 0.05$ & $0.45 \pm 0.05$ & $0.4 \pm 0.07$ \\
Overall mean & $0.389 \pm 0.07$ & $0.394 \pm 0.07$ & $0.406 \pm 0.06$ & $0.403 \pm 0.06$ \\
\hline
\end{tabular}

$D_{1}, D_{2}, D_{3}$, and $D_{4}$ referred to different diets, and $T_{1}, T_{2}$, and $T_{3}$ referred to temperatures $T_{24}{ }^{\circ} \mathrm{C}, T_{28}{ }^{\circ} \mathrm{C}$, and $T_{32}{ }^{\circ} \mathrm{C}$ that used for the experiment, respectively

Table 4: Concentration of $\mathrm{LH} \mu / 1$ in female $C$. gariepinus

\begin{tabular}{lccccc} 
Parameter & \multicolumn{3}{c}{ Diet } & Overall mean \\
\cline { 2 - 5 } \multicolumn{1}{l}{ Temperature } & $\boldsymbol{D}_{1}$ & $\boldsymbol{D}_{2}$ & $\boldsymbol{D}_{3}$ & $\boldsymbol{D}_{4}$ \\
$T_{1}$ & & & & $0.546 \pm 0.03$ \\
$T_{2}$ & $0.46 \pm 0.13$ & $0.431 \pm 0.03$ & $0.437 \pm 0.06$ & $0.57 \pm 0.03$ & $0.468 \pm 0.08$ \\
$T_{3}$ & $0.437 \pm 0.09$ & $0.528 \pm 0.06$ & $0.587 \pm 0.05$ & $0.763 \pm 0.08$ & $0.53 \pm 0.08$ \\
Overall mean & $0.854 \pm 0.03$ & $0.807 \pm 0.07$ & $0.619 \pm 0.03$ & $0.626 \pm 0.11$ & $0.587 \pm 0.1$ \\
\hline
\end{tabular}

$D_{1}, D_{2}, D_{3}$, and $D_{4}$ referred to different diets, and $T_{1}, T_{2}$, and $T_{3}$ referred to temperatures $T_{24}{ }^{\circ} \mathrm{C}, T_{28}{ }^{\circ} \mathrm{C}$, and $T_{32}{ }^{\circ} \mathrm{C}$ that used for the experiment, respectively 
by temperature and diet. The concentration of $\mathrm{LH}$ positively increased with temperature from $24^{\circ} \mathrm{C}$ to $32^{\circ} \mathrm{C}$. The highest concentration of LH was recorded in $C$. gariepinus with fishmeal-based diet $\left(D_{1}\right)$ while soybean meal-based diet $\left(D_{2}\right)$, reduced the concentration of LH in this study. The concentration of FSH reached at its maximum at $28^{\circ} \mathrm{C}$ then decreased with increasing temperature up to $32^{\circ} \mathrm{C}$. The FSH and $\mathrm{LH}$ are important for better egg quality and successful fish reproduction. The fishmeal-based diet $\left(D_{1}\right)$ produced the highest concentration of FSH while pea-meal based $\operatorname{diet}\left(D_{3}\right)$ produced the lowest concentration of FSH in this study. Water temperature regulates the level of GH. The best temperature for optimum production of $\mathrm{GH}$ in C. gariepinus was found to be $28^{\circ} \mathrm{C}$ in this study. The level of hormones increased from $24^{\circ} \mathrm{C}$ to $28^{\circ} \mathrm{C}$ then decreased at a higher temperature. Fish diet also has an essential role in $\mathrm{GH}$ regulation. It was observed in this study that fishmeal-based diet $\left(D_{1}\right)$ increases the concentration of GH and pea-meal based diet reduces the concentration of $\mathrm{GH}$ in $C$. gariepinus.

\subsection{Sperm Morphometries and Gonadal Weight}

The effect of different diets and temperature and temperate and diet combinations on the sperm head, mid-piece, and tail of sperm of male fish of $C$. gariepinus is shown in Table 7. The sperm head length showed significant $(P<0.05)$ difference between variable diets and temperature and to different diet and temperature combinations. The highest length which was recorded was $2.348 \pm 0.9 \mu \mathrm{m}$ at $T_{32}$ and $D_{4}$ and the lowest length was $1.395 \pm 0.2 \mu \mathrm{m}$ at $T_{32}$ and $D_{2}$, respectively. The maximum length $(2.348 \pm 0.9 \mu \mathrm{m})$ of sperm head was found at the experimental condition of $D_{4}$ and $T_{3}$ while the minimum length $(1.18 \pm 0.03 \mu \mathrm{m})$ was found at $T_{24}$ and $D_{2}$. The sperm head width showed a significant difference $(P<0.05)$ to diet as well as temperature. The length of sperm mid-piece showed a significant difference between all diets, temperature, and the combined effect of diet and temperature $(P<0.05)$. The maximum and minimum values are $425.00 \pm 75.20 \mu \mathrm{m}$ and $247.75 \pm 73.11 \mu \mathrm{m}$ at $D_{4}$ and $T_{3}$ and $D_{4}$ and $T_{1}$, respectively. The width of sperm mid-piece was statistically not significant at any temperature or diets, but the combined effect of diet and temperature showed significant $(P<0.05)$ difference in the width in the midpiece of sperm of $C$. gariepinus. The maximum width of sperm midpiece was $539.44 \pm 34.67 \mu \mathrm{m}$ at $D_{1}$ and $T_{1}$ and the minimum value was $292.13 \pm 5.25 \mu \mathrm{m}$ at $T_{24}$ and $D_{4}$. The tail length of the sperms showed a significant difference between all diets, temperature, and their combinations. The highest and lowest values are $41.95 \pm 6.99$ $\mu \mathrm{m}$ and $9.09 \pm 5.2 \mu \mathrm{m}$ at $T_{24}$ and $D_{2}$ and $T_{32}$ and $D_{1}$, respectively. On the other hand, the width of the sperm tail was significantly different for diet and their combined effect $(P<0.05)$, but the temperature showed no significant difference on sperm tail length at $P<0.05$. The highest and lowest values are $230.80 \pm 36.90 \mu \mathrm{m}$ and $155.75 \pm 38.24 \mu \mathrm{m}$ at $T_{32}$ and $D_{4}$ and $T_{28}$ and $D_{3}$, respectively. Sperm length determined the speed of the sperm which is important in fertilization success; a longer flagellum means a stronger propulsive force [30,31]. Various studies showed that there is no evidence of sperm morphology on sperm quality [32]. Other studies done in Salmon indicate that there is no influence of sperm morphology on the ejaculate longevity as well as no correlation between spermatocrit and sperm morphology [33].

Various combinations of temperature and diets showed a significant $(P<0.05)$ difference in the relative weight of testis of the male $C$. gariepinus. The highest and lower values were $0.935 \% \pm 0.6 \%$ and $0.282 \% \pm 0.13 \%$ at $T_{24}$ and $D_{3}$ and $T_{32}$ and $D_{4}$, respectively, shown in Tables 8 .

The result showed that treatments with both temperature and diet gave significant differences between the average relative weight of the ovary of the catfish $C$. gariepinus $(P<0.05) . D_{1}$ and $T_{3}$ showed the highest relative weight of ovary as $17.266 \% \pm 6.89 \%$ and the lower value at $T_{24}$ and $D_{2}$ as $11.728 \% \pm 5.33 \%$ as shown in Tables 9 and 10 .

Unlike capture fisheries, the aquaculture involves human intervention in fish breeding to exceed the production and yield of the natural environment [34]. Temperature and diet management will improve gonadotropins and liver enzymes to achieve an effective development of fish sperms and ova to get successful egg fertilization and eventually maximize the fish number in the system. One of the most important problems of aquaculture development is the scarcity of fish fingerlings of the chosen species for culture [35]. We need to adjust temperature and diet quality to produce enough seeds for aquaculture development of the fish. This study indicates that the gonads or gonadosomatic index, quality of sperms, levels of gonadotropins, and liver enzymes

Table 5: Concentration of (FSH) $\mu / 1$ in C. gariepinus males and females at the end of the experiment

\begin{tabular}{lccccc} 
Parameter & \multicolumn{3}{c}{ Diet } & Overall mean \\
\cline { 2 - 5 } & \multicolumn{1}{c}{$\boldsymbol{D}_{\mathbf{1}}$} & $\boldsymbol{D}_{2}$ & $\boldsymbol{D}_{3}$ & $\boldsymbol{D}_{4}$ \\
Temperature & & & & $0.755 \pm 0.03$ \\
$T_{1}$ & $0.737 \pm 0.03$ & $0.7 \pm 0.04$ & $0.742 \pm 0.03$ & $0.713 \pm 0.03$ & $0.733 \pm 0.04$ \\
$T_{2}$ & $0.789 \pm 0.01$ & $0.759 \pm 0.04$ & $0.738 \pm 0.01$ & $0.597 \pm 0.04$ & $0.585 \pm 0.03$ \\
$T_{3}$ & $0.609 \pm 0.03$ & $0.57 \pm 0.02$ & $0.566 \pm 0.02$ & $0.688 \pm 0.08$ & $0.689 \pm 0.08$ \\
Overall mean & $0.712 \pm 0.08$ & $0.676 \pm 0.09$ & $0.682 \pm 0.09$ & \\
\hline
\end{tabular}

$D_{1}, D_{2}, D_{3}$, and $D_{4}$ referred to different diets, and $T_{1}, T_{2}$, and $T_{3}$ referred to temperatures $T_{24}{ }^{\circ} \mathrm{C}, T_{28}{ }^{\circ} \mathrm{C}$, and $T_{32}{ }^{\circ} \mathrm{C}$ that used for the experiment, respectively

Table 6: Concentration of $\mathrm{GH} \mathrm{ng} / \mathrm{ml}$ in the blood of C. gariepinus males and females at the end of the experiment

\begin{tabular}{lccccc} 
Parameter & \multicolumn{3}{c}{ Diet } & Overall mean \\
\cline { 2 - 5 } & \multicolumn{1}{c}{$\boldsymbol{D}_{\mathbf{1}}$} & $\boldsymbol{D}_{\mathbf{2}}$ & $\boldsymbol{D}_{\mathbf{3}}$ & $\boldsymbol{D}_{4}$ \\
Temperature & & & & $0.855 \pm 0.02$ \\
$T_{1}$ & $0.863 \pm 0.02$ & $0.831 \pm 0.03$ & $0.842 \pm 0.03$ & $0.859 \pm 0.02$ & $0.848 \pm 0.03$ \\
$T_{2}$ & $0.905 \pm 0.02$ & $0.833 \pm 0.02$ & $0.819 \pm 0.02$ & $0.807 \pm 0.02$ & $0.79 \pm 0.03$ \\
$T_{3}$ & $0.813 \pm 0.02$ & $0.796 \pm 0.01$ & $0.744 \pm 0.02$ & $0.84 \pm 0.03$ & $0.831 \pm 0.04$ \\
Overall mean & $0.86 \pm 0.04$ & $0.82 \pm 0.02$ & $0.802 \pm 0.05$ & \\
\hline
\end{tabular}

$D_{1}, D_{2}, D_{3}$, and $D_{4}$ referred to different diets, and $T_{1}, T_{2}$, and $T_{3}$ referred to temperatures $T_{24}{ }^{\circ} \mathrm{C}, T_{28}{ }^{\circ} \mathrm{C}$, and $T_{32}{ }^{\circ} \mathrm{C}$ that used for the experiment, respectively 
Table 7: Average morphometry $(\mu \mathrm{m})$ of different parts of sperm of the $C$. gariepinus treated with different diets and temperature during the period of the experiment

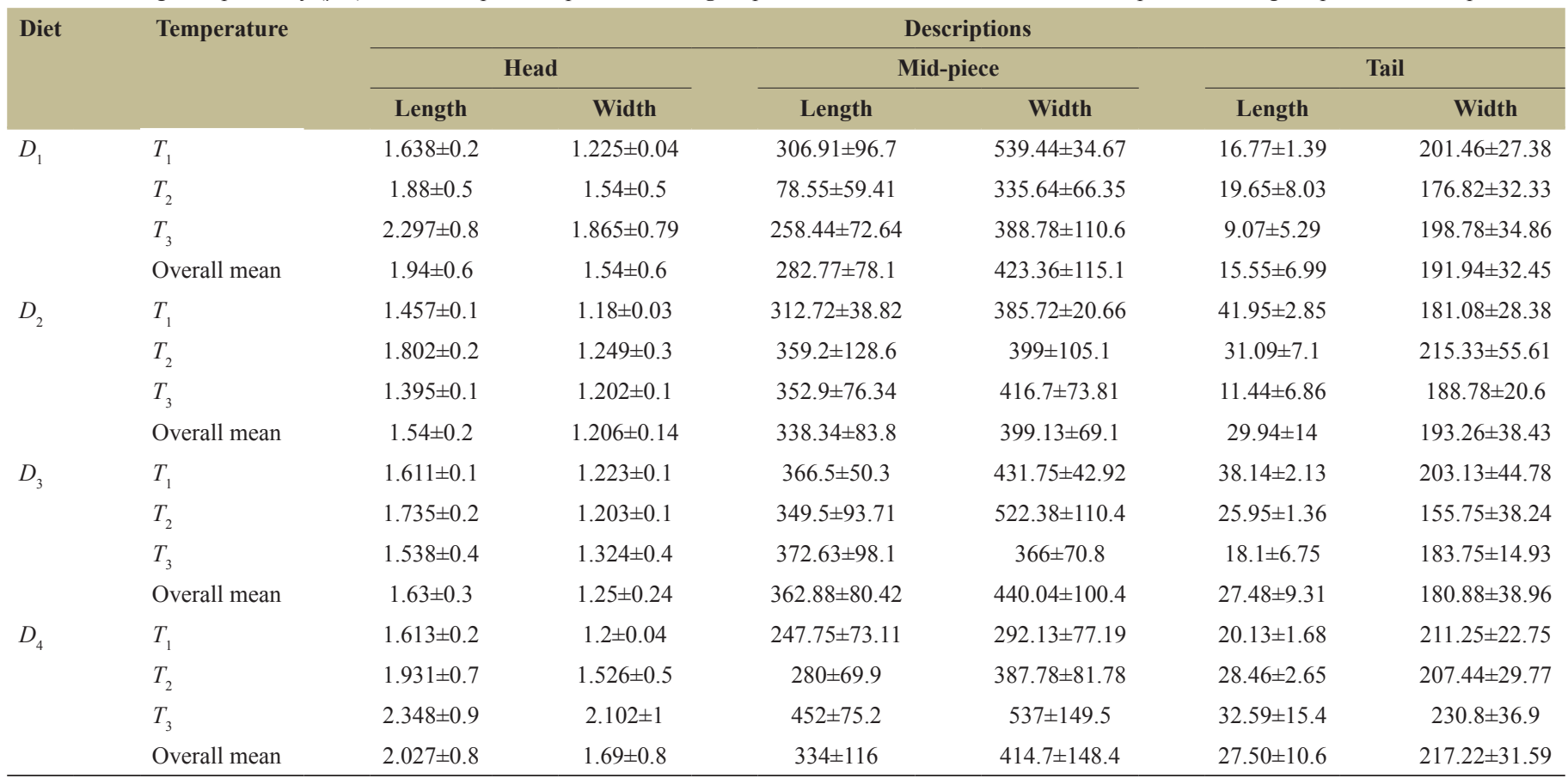

$D_{1}, D_{2}, D_{3}$, and $D_{4}$ referred to different diets, and $T_{1}, T_{2}$, and $T_{3}$ referred to temperatures $T_{24}{ }^{\circ} \mathrm{C}, T_{28}{ }^{\circ} \mathrm{C}$, and $T_{32}{ }^{\circ} \mathrm{C}$ that used for the experiment, respectively

Table 8: Average testis/body weight \% of African Catfish C. gariepinus

\begin{tabular}{lccccc}
\multicolumn{1}{c}{ Parameter } & \multicolumn{3}{c}{ Diet } & Overall mean \\
\cline { 2 - 6 } & \multicolumn{1}{c}{$\boldsymbol{D}_{\mathbf{1}}$} & $\boldsymbol{D}_{2}$ & $\boldsymbol{D}_{3}$ & $\boldsymbol{D}_{4}$ \\
Temperature & & & & $0.935 \pm 0.19$ \\
$T_{1}$ & $0.678 \pm 0.21$ & $0.68 \pm 0.3$ & $0.935 \pm 0.6$ & $0.787 \pm 0.22$ & $0.807 \pm 0.37$ \\
$T_{2}$ & $0.834 \pm 0.24$ & $0.68 \pm 0.29$ & $0.615 \pm 0.25$ & $0.282 \pm 0.13$ & $0.561 \pm 0.28$ \\
$T_{3}$ & $0.45 \pm 0.2$ & $0.73 \pm 0.29$ & $0.76 \pm 0.17$ & $0.679 \pm 0.33$ & $0.7 \pm 0.32$ \\
Overall mean & $0.654 \pm 0.26$ & $0.697 \pm 0.29$ & $0.77 \pm 0.4$ & & \\
\hline
\end{tabular}

$D_{1}, D_{2}, D_{3}$, and $D_{4}$ referred to different diets, and $T_{1}, T_{2}$, and $T_{3}$ referred to temperatures $T_{24}{ }^{\circ} \mathrm{C}, T_{28}{ }^{\circ} \mathrm{C}$, and $T_{32}{ }^{\circ} \mathrm{C}$ that used for the experiment respectively

Table 9: Absolute and relative fecundity of $C$. gariepinus

\begin{tabular}{lccccc} 
Parameter & Length of fish $(\mathbf{c m})$ & Weight of fish (g) & Absolute fecundity & $\begin{array}{c}\text { Relative weight of } \\
\text { testis (\%) }\end{array}$ & $\begin{array}{c}\text { Relative weight of } \\
\text { ovary }(\%)\end{array}$ \\
Range & $27.80 \pm 2.06-34.00 \pm 1.23$ & $169.20 \pm 8.12-277.85 \pm 11.31$ & $54,060 \pm 489.06-294.315 \pm 1,987.63$ & $0.935 \pm 0.60-0.282 \pm 0.13$ & $11.728 \pm 5.33-$ \\
Mean & $31.13 \pm 3.97$ & $217.51 \pm 10.98$ & $125.178 \pm 607.72$ & $0.7 \pm 0.32$ & $14.684 \pm 4.86$ \\
\hline
\end{tabular}

cm: Centimeter, g: Gram

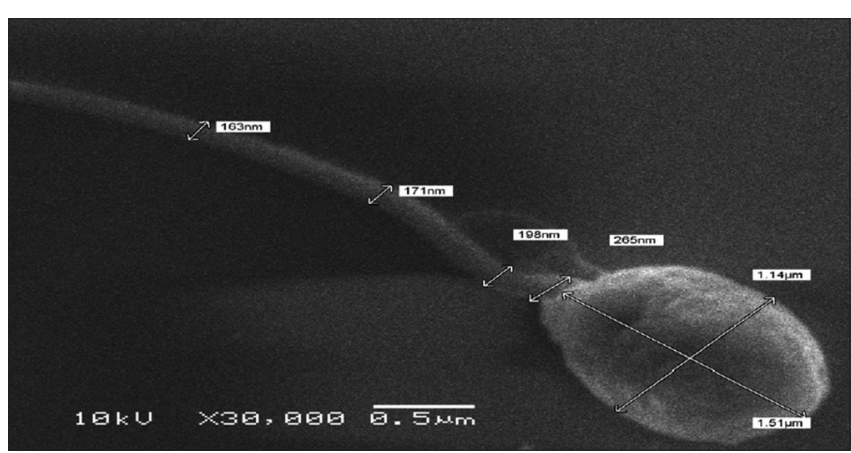

Figure 1: Scanning electron micrograph showing measurements of head, midpiece, and tail of C. gariepinus spermatozoa showed the best performance at the temperature of $28^{\circ} \mathrm{C}$ and a diet of fishmeal and soy-meal. These parameters would provide the baseline to attain the best production for the aquaculture of $C$. gariepinus in future.

\subsection{Fecundity}

Fecundity is a very essential characteristic of fish culture because it gives an indication of the average reproductive feature of the fish [36]. The fecundity of C. gariepinus varied between 54,060 and 294,315 in this study; however, the absolute fecundity was calculated $125,178 \pm$ 607.72 at $T_{28}$ and $D_{2}$ [Table 9].

The regression analysis between fish fecundity and fish weight showed a high correlation coefficient $\left(r^{2}\right)$ between the logarithm of fecundity and weight throughout the experimentation equal to 0.861 [Figure 2]. 
Table 10: Average relative weight $\%$ of ovary of African Catfish C. gariepinusa at the end of experimentation period

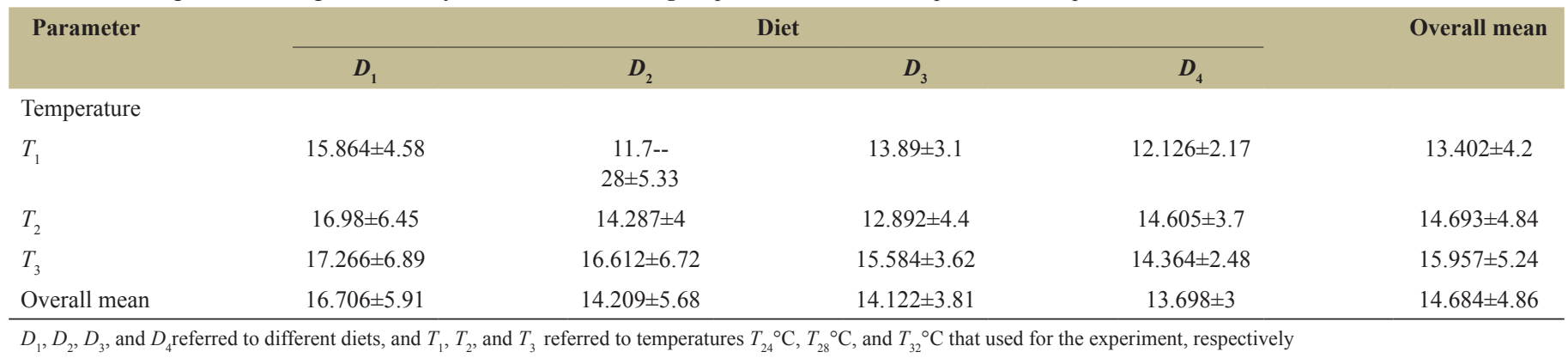

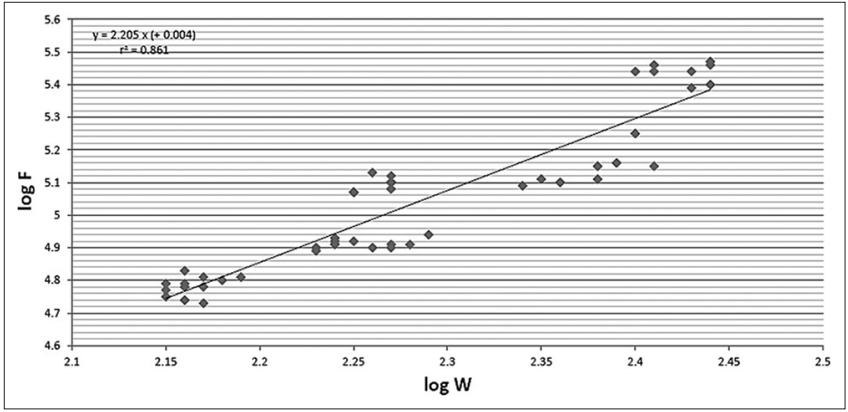

Figure 2: The relationship between log of fecundity and log of the weight of $C$. gariepinus tested with different diets and temperature for 4 months. $\log =\operatorname{logarithm} ; \mathrm{F}=$ fish fecundity; $\mathrm{W}=$ fish weight

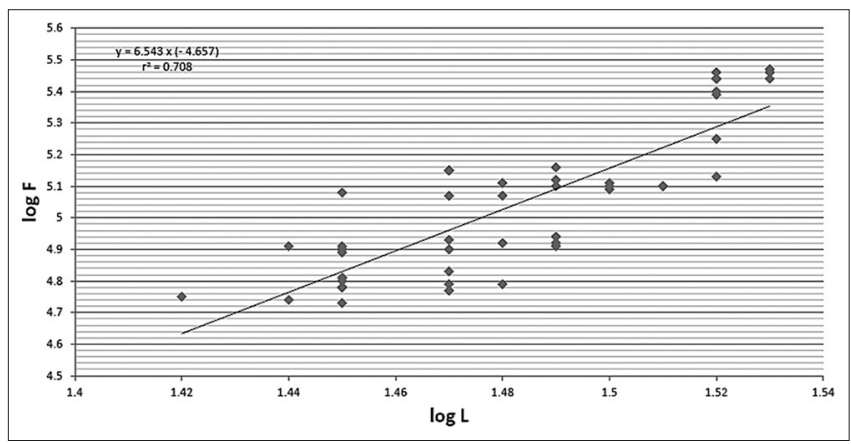

Figure 3: The relationship between logarithm of fecundity and total length of $\mathrm{C}$ gariepinus tested with different diets and temperature for 4 months.

$\log =\operatorname{logarithm} ; \mathrm{F}=$ fish fecundity; $\mathrm{L}=$ fish length

The correlation coefficient $\left(r^{2}\right)$ for the regression of logarithm of fecundity and total length also showed a similar result for $C$. gariepinus throughout the experimentation period with $r^{2}=0.708$ [Figure 3].

The total fecundity of fish is the total number of eggs of fish ovaries, while the relative fecundity is the amount of ovary egg per gram. Fish fecundity and egg qualities are important factors for fish breeding and the success of aquaculture. The present study revealed a high correlation between the logarithm of total fecundity and logarithm of both weight and length of the $C$. gariepinus with $R^{2}$ always $>0.70$, which mean that fecundity of C. gariepinus increased with weight and length of the fish. Similar kind of findings has also been reported in previous studies [35,37-39].

\section{CONCLUSION}

The effect of temperature and type of food on the growth, metabolism, and the physiological status of different species of fish has been studied previously [40-43]. The role of temperature and food type on fish growth and the performance of reproductive enzymes and hormones have been evaluated in $C$. gariepinus to achieve the successful aquaculture of this economically important catfish. The data in this study suggest an optimum temperate of $28^{\circ} \mathrm{C}$ for the best growth, fish fecundity and health of C. gariepinus. Moreover, the fishmeal and soymeal-based diets would be beneficial to attain the best growth and fecundity of this fish when combined with the optimum water temperature.

\section{ACKNOWLEDGMENTS}

The project was supported by general directorate of medical services of the armed forces, Prince Sultan Military Medical City, Scientific research Centre.

\section{REFERENCES}

1. Adewolu MA, Ogunsanmi AO, Yunusa A. Studies on growth performance and feed utilization of two clariid catfish and their hybrid reared under different culture systems. Eur J Sci Res 2008;23:252-60.

2. Hecht T, Oellermann L, Verheust L. Perspectives on Clariid catfish culture in Africa. Aquat Living Resour 1996;9:197-206.

3. Micha JC. Induced breeding of Clarias species. Aquacult Bull 1973;4:3-4.

4. Clay D. Utilization of plant materials by juvenile African catfish (Clarias gariepinus) and its importance in fish culture. J Limnol Soc South Afr 1981;7:4756.

5. Yamamoto T, Unuma T, Akiyama T. The influence of dietary protein and fat levels on tissue free amino acid levels of fingerling rainbow trout (Oncorhynchus mykiss). Aquaculture 2000;182:353-72.

6. Baruah K, Norouzitallab P, Debnath D, Pal AK, Sahu NP. Organic acids as non-antibiotic nutraceuticals in fish and prawn feed. Aquacult Health Int 2008;12:4-6.

7. Barton BA. Stress in fishes: A diversity of responses with particular reference to changes in circulating orticosteroids. Integr Comp Biol 2002;42:517-25.

8. Liu B, Xie J, Ge XP, Miao LH, Wang GY. Effect of high dietary carbohydrate on growth, serum physiological response, and hepatic heat shock cognate protein 70 expressions of the top-mouth culter (Erythroculter ilishaeformis) Bleeker. Fish Sci 2012;78:613-23.

9. Gardeur JN, Mathis N, Kobilinsky A, Brun-Bellut J. Simultaneous effects of nutritional and environmental factors on growth and flesh quality of Perca fluviatilis using a fractional factorial design study. Aquaculture 2007;273:50-63.

10. Hochachka PW, Somero GN. Biochemical Adaptation. Princeton, New Jersey: Princeton University Press; 1984. p. 525.

11. Velmurugan B, Selvanayagam M, Cengiz EI, Unlu E. The effects of fenvalerate on different tissues of freshwater fish Cirrhinus mrigala. J Environ Sci Health B 2007;42:157-63.

12. Figueroa J, San Martín R, Flores C, Grothusen H, Kausel G. Seasonal modulation of growth hormone mRNA and protein levels in carp pituitary: Evidence for two expressed genes. J Comp Physiol B Biochem Syst Environ Physiol 2005;175:185-92. 
13. Lynn SG, Powell KA, Westneat DF, Shepherd BS. Seasonal and sexspecific mRNA levels of key endocrine genes in adult yellow perch (Perca flavescens) from Lake Erie. Mar Biotechnol 2009;11:210-22.

14. Gómez-Requeni P, Néstor Kraemer M, Canosa LF. Regulation of somatic growth and gene expression of the GH-IGF system and PRP-PACAP by dietary lipid level in early juveniles of a teleost fish, the pejerrey (Odontesthes bonariensis). J Comp Physiol B Biochem Syst Environ Physiol 2012;182:517-30.

15. Zhou C, Liu B, Xie J, Ge X, Xu P, Zhou Q, et al. Effect of dietary carbohydrate levels on the growth performance, blood chemistry, hepatic enzyme activities and growth hormone gene expression of the Wuchang bream (Megalobrama amblycephala). Isr J Aquacult Bamidgeh 2013;65:882-92.

16. Quérat B, Sellouk A, Salmon C. Phylogenetic analysis of the vertebrate glycoprotein hormone family including new sequences of sturgeon (Acipenser baeri) $\beta$ subunits of two gonadotropins and the thyroid-stimulating hormone. Biol Reprod 2000;63:222-8.

17. Yaron Z, Gur G, Melamed P, Rosenfeld H, Elizur A, Levavi-Sivan B. Regulation of fish gonadotropins. Int Rev Cytol 2003;225:131-85.

18. Kim DJ, Suzuki Y, Aida K. The control mechanism of gonadotropinreleasing hormone and dopamine on gonadotropin release from cultured pituitary cells of rainbow trout Oncorhynchus mykiss at different reproductive stages. Fish Aquat Sci 2011;14:379-88.

19. Snyder DE. Fish eggs and larvae. In: Nielsen LA, Johnson DL, editors. Fisheries Techniques. Bethesda, Maryland: American Fishery Society; 1983. p. 165-97.

20. Reitman S, Frankel S. A colorimetric method for the determination of serum glutamic oxalacetic and glutamic pyruvic transaminases. Am J Clin Pathol 1957;28:56-63.

21. Taddei AR, Barbato F, Abelli L, Canese S, Moretti F, Rana KJ, et al. Is cryopreservation a homogeneous process? Ultrastructure and motility of untreated, prefreezing, and postthawed spermatozoa of Diplodus puntazzo (Cetti). Cryobiology 2001;42:244-55.

22. James PS, Gupta TR, Shanbhogue SL. Some aspects of the biology of ribbon fish, Trichiurus lepturus (Linnaeus). J Mar Biol 1978;290:120-37.

23. Keenlyne KD, Grossman EM, Jenkins LG. Fecundity of the pallid sturgeon. Trans Am Fish Soc 1992;121:139-40.

24. Sokal RR, Rohlf FJ. Biometry: The Principles and Practice of Statistics in Biological Research. New York: W.H. Freeman; 2000.

25. Parker RE. An Introduction to Statistics for Biologists. Warszawa: PWN-Polish Scientific Publishers; 1978. p. 133.

26. Krajnovic-Ozretic M, Ozretic B. Estimation of the enzymes LDH, GOT and GPT in plasma of grey mullet Mugil auratus and their significance in liver intoxication. Dis Aquat Org 1987;3:187-93.

27. Nelson DL, Cox MM. Lehninger Principles of Biochemistry. New York: Worth Publishers; 2000.

28. Ahmad Z, Al-Ghanim KA, Al-Balawi HF, Al-Musned F, Mahboob S. Study on acute toxicity, heamatological and biochemical alterations induced by the exposure of DDT to catfish. Fresenius Environ Bull 2016;25:5935-43.

29. Sayed AE, Mahmoud UM, Mekkawy IA. Reproductive biomarkers to identify endocrine disruption in Clarias gariepinus exposed to 4 nonylphenol. Ecotoxicol Environ Saf 2012;78:310-9.
30. Katz DF, Drobnis EZ. Analysis and interpretation of the forces generated by spermatozoa. In: Bavister BD, Cummins J, Roldan ER, editors. Fertilization in Mammals. Norwell, MA: Serono Symposia; 1990. p. 125-37.

31. Gomendio M, Roldan EM. Sperm competition influences sperm size in mammals. Proc R Soc London Ser 1991;B243:181-5.

32. Leach BJ. Cornpetition and the Evolution of Sperm Characteristics in Pacific Salmon (Oncorhynchus spp). A Thesis Submitted to the Department of Biology in Conformity with the Requirements for the Degree of Master of Science Queen's University. Kingston, ON, Canada; 1997. p. 111.

33. Vladic TV, Afzelius BA, Bronnikov GE. Sperm quality as reflected through morphology in salmon alternative life histories. Biol Reprod 2002;66:98-105.

34. Ndimele PE, Owodeinde FG. Comparative reproductive and growth performance of Clarias gariepinus (Burchell, 1822) and its hybrid induced with synthetic hormone and pituitary gland of Clarias gariepinus. Turk J Fish Aquat Sci 2012;12:619-26.

35. Adewolu MA, Ademji CA, Adejobi AB. Feed utilization, growth and survival of Clarias gariepinus (Burchell 1822) fingerlings cultured under different photoperiods. Aquaculture 2008;283:64-7.

36. Eyo VO, Ekanem AP, Ajom VA. Fecundity studies of the African catfish Clarias gariepinus (Burchell, 1822) fed coppens feed and Unical. Aqua feed in circular concrete tanks. J Coast Life Med 2016;4:531-5

37. Gupta SK, Gupta PC. General and Applied Ichthyology: Fish and Fisheries. New Delhi, India: S. Chand and Co. Ltd.; 2006. p. 1130.

38. Yusuf K, Dada SA, Abari MA. Length-weight relationship, fecundity and gonadal development of the African catfish (Clarias gariepinus) from Doma Dam, Nasarawa State, Nigeria. Polym Adv Technol 2013;9:47-58

39. Absalom KV, Anpe JA, Igoche LE, Okunsebor SA. Fecundity and egg size of Clarias Gariepinus in Pandam Lake, Quan-Pan L.G.A. Plateau State, Nigeria. IOSR J Agric Vet Sci 2017;10:19-22.

40. Degani G, Ben-Zvi Y, Levanon D. The effect of different dietary protein sources and temperatures on growth and feed utilisation of African catfish Clarias gariepinus (Burchell). Bamidgeh 1988;40:113-7.

41. Burel C, Person-Le Ruyet J, Gaumet F, LeRoux A, Sévère A, Boeuf G. Effects of temperature on growth and metabolism in juvenile turbot. J Fish Biol 1996;49:678-92.

42. Nahar Z, Azad Shah AK, Bhandari RK, Ali MH, Dewan S. Effect of different feeds on growth, survival and production of African catfish (Clarias gariepinus Burchell). Bangladesh J Fish Res 2000;4:121-6.

43. Al-Deghayem WA, Al-Balawi HF, Kaneal SA, Suliman EM. Gonadosomatic index and some hematological parameters in African catfish Clarias gariepinus (Burchell, 1822) as affected by feed type and temperature level. Braz Arch Biol Technol 2017;60:1-9.

\footnotetext{
How to cite this article:

Al-Deghayem WAA, Suliman EAM, The effects of diet and temperature on enzymes, hormones, and fecundity of the African Catfish Clarias gariepinus (Burchell 1822). J App Biol Biotech. 2019;7(02):71-77.

DOI: 10.7324/JABB.2019.70213
} 